\title{
VALENTYN LEONIDOVYCH GANUL
}

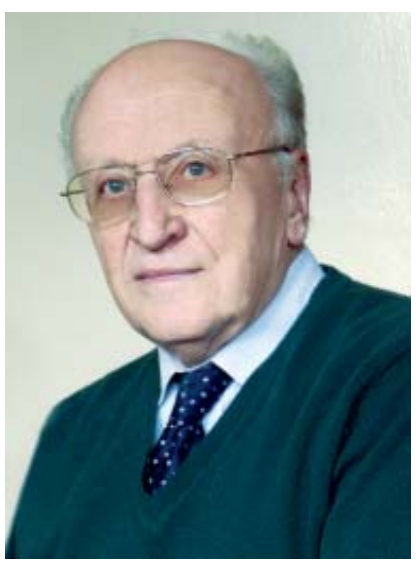

Ukrainian oncologysuffered a grievous loss. In March 29, 2015, aged 85, Valentyn Leonidovych Ganul died. Prof. Ganul was an outstanding oncologist, a virtuoso surgeon, founder of the Ukrainian School of Thought in Thoracic Cancer Surgery, Commander of the Order of Friendship of Peoples, Corresponding Member of National Academy of Sciences (NAS) and National Academy of Medical Sciences (NAMS) of Ukraine, Memorial R.E. Kavetsky Award Holder of the NAS of Ukraine, Head of the Research Department of Thoracic Cancer Surgery of the National Cancer Institute.

Valentyn Ganul was born in Poltava, Ukraine. In 1954, he graduated from the Kharkiv Medical Institute. He started his working career as an attending physician of the Kyiv Regional Oncological Center. In 1958-1959, under the guidance of well-known thoracic surgeon Mykola Amosov, Valentyn Leonidovych worked as a doctor and researcher at the Department of Thoracic Surgery in Kyiv Research Institute of Tuberculosis and Pulmonology.

Since 1959, Valentyn Ganul had been working as an assistant, and since 1964 (after defending his doctoral thesis in 1971) as an Associate Professor in the Department of Oncology of the Kyiv Institute for Physicians' Continuing Education. During these years, he became an experienced clinician-oncologist, a brilliant surgeon, thoughtful scholar and erudite lecturer.

By the early 1970s, Valentyn Ganul's research interests focused on thoracic oncology, which is among the most difficultfields of clinical oncology. In 1971, he headed the Department for Thoracic Oncology of the National Cancer Institute (at that time, the Kyiv Research Radiological and Oncologic Institute of the Health Ministry of the USSR). Since that time, all his efforts and talenthad focused on the developmentand improvement of treatment methods for lung cancer, mediastinal tumors, cancer of the esophagus, and gastric cardia cancer. In 1983, he defended his doctoral thesis entitled "Surgical and Combined Treatment of Patients with Esophageal and Cardioesophageal Cancer", which was a significant scientific contribution to oncology. In 1988, Valentyn Ganul was awarded the academic title of professor.

Since 1974, in addition to heading the Department of Thoracic Oncology, Valentyn Ganul occupied leading positions in the Institute as the Deputy Director for Research, since 1979 as the Deputy Director of the Clinic, in 1987-1991 as the Director of the Institute, and in 19911999 as the Head of the Clinical and Surgical Department.
Having dedicated 40 years of his life to thoracic oncology, Prof. Ganul became an outstanding Ukrainian surgeon and researcher. He developed and perfected many types of techniques used in surgery of esophagus, cardia, lung, mediastinal tumors. His unique technique for the formation of esophageal-gastric bypass was widely recognized in the CIS countries. He performed prominent scientific studies in the field of combined and complex treatment of cancer. Under Prof. Ganul's leadership, effective methods were developed such as preoperative radiation therapy, either alone or in combination with a variety of radiomodifiers; adjuvant and neoadjuvant chemotherapy; immunotherapy.

The research department, headed by Valentyn Ganul, has become one of the world's most prominent centers for surgical treatment of patients with cancer of the esophagus and Ukraine's largest center for treatment of patients with lung cancer. Prof. Ganul and his team and students have gained unique experience in treating patients with malignant thymoma. Valentyn Ganul was a founder of a school of thoughts in Thoracic Cancer Surgery. Under his supervision, 6 doctoral and 12 candidate theses were defended. Valentyn Ganul authored about 200 scientific papers, including 7 monographs, and 11 inventions.

For outstanding service to health care and medical science, Valentyn Ganul was awarded the title of Honored Worker of Health Care in 1974 and the Order of Friendship of Peoples in 1981. In 2009, he was awarded the title of Honored Doctor of Ukraine.

In 1985, the $8^{\text {th }}$ Congress of Ukrainian Oncologistselected Valentyn Ganul as the Chairman of the Presidium of the Ukrainian Scientific-Medical Society of Oncologists. In 1991, Prof. Ganul was elected a member of the NAS of Ukraine, and in 1993 - a member of the NAMS of Ukraine. Valentyn Ganul was a member of specialized councils for defending theses in the fields of Oncology and Radiology, deputy chief editor of the "Oncology" quarterly, a member of the editorial board of the "Experimental Oncology". A talented scientist, he featured high responsibility and demands to himself and his followers and an extraordinary intuition. Respectful, modest, and sincere, he earned respectand deep gratitude from patients and colleagues.

An outstanding scientist and oncologist, he chose health care and service to the Ukrainian people as his lifework. The memory of Valentyn Ganul, an talented surgeon and an extremely noble man, will always remain in our hearts. He devoted his life to treatment of thousands of patients, and his successes in this field are the best memorial to the doctor and oncologist.

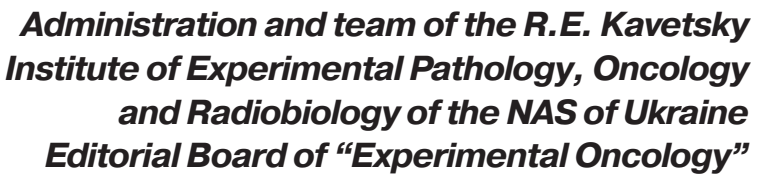

